\title{
Effects of the gem clam Gemma gemma on early post-settlement emigration, growth and survival of the hard clam Mercenaria mercenaria
}

\author{
In-Young Ahn ${ }^{1}$, Glenn Lopez ${ }^{2, *}$, Robert Malouf ${ }^{3}$ \\ ${ }^{1}$ Polar Research Center, Korea Ocean Research and Development Institute (KORDI), Ansan, PO Box 29, Seoul 425-600, \\ Republic of Korea \\ ${ }^{2}$ Marine Sciences Research Center, State University of New York at Stony Brook, New York 11794, USA \\ ${ }^{3}$ Oregon Sea Grant Institute, Oregon State University, Corvallis, Oregon 97331, USA
}

\begin{abstract}
The purpose of this study was to determine the effects of dense patches of adult Gemma gemma, food concentration, and substrate type on emigration, growth and survival of newly settled Mercenaria mercenaria. Hard clams emigrated more in the presence of G. gemma than in its absence in both laboratory and field experiments. The overall effect of reduced food was increased emigration. Presence of $G$. gemma in sand enhanced hard clam growth while not affecting survival, but in muddy sand growth and survival decreased. Hard clams grew best in muddy sand without gem clams. In further experiments hard clams grew faster in shallower sediments and slower with addition of $G$. gemma biodeposits. We conclude that undisturbed post-settlement $M$. mercenaria grow more slowly than they are capable of because they spend part of the time buried, presumably to avoid surface predators. Clams that are kept near the sediment surface, either because of sedimentary properties or interaction with spatial competitors, grow considerably faster than undisturbed clams in sand. This interpretation implies a trade-off between opposing selective pressures such that clams partition time between the necessary risk of feeding and the safe but energetically unprofitable sub-surface refuge from predation.
\end{abstract}

\section{INTRODUCTION}

Established benthos may affect the early recruitment of benthic animals through ingestion or filtration of larvae, sediment reworking, competition and predation. Woodin (1976) predicted that inhibition of larval recruitment by adult organisms in the sediment is an important mechanism in controlling soft-bottom community structure. Experimental studies demonstrated that resident adults negatively impact settling and newly settled infauna (Williams 1980, Wilson 1980, Brenchley 1981, Levin 1981, Peterson 1982, Gallagher et al. 1983, Luckenbach 1984, Tamaki 1985, Woodin 1985\}.

In this study we investigated the effect of gem clams Gemma gemma on newly settled hard clams Mercenaria mercenaria. The gem clam, a small $(5 \mathrm{~mm})$

\footnotetext{
- Addressee for correspondence
}

suspension-feeding bivalve, is one of the most abundant infaunal species in shallow estuarine benthos (Bradley \& Cooke 1959, Sanders et al. 1962, Sellmer 1967. Green \& Hobson 1970, Maurer et al. 1978, Woodin 1981, Thomson 1982, Botton 1984). Adult populations often reach summer densities of $10^{5}$ ind. $\mathrm{m}^{-2}$ (Bradley \& Cooke 1959, Sanders et al. 1962, Sellmer 1967, Green \& Hobson 1970, Thomson 1982). It shares with $M$. mercenaria much of the same habitat and geographic range. It is morphologically similar, particularly in siphonal structure, to newly settled hard clams and feeds mostly at the sediment-water interface (Sellmer 1967). Bradley \& Cooke (1959) and Sanders et al. (1962) observed an inverse relationship between abundances of $G$. gemma and other suspension-feeding bivalves, and suggested that dense G. gemma populations inhibit recruitment of other suspension feeders by outcompeting the tiny spat for food. 
Ahn et al. (1993) demonstrated in laboratory experiments that Mercenaria mercenaria larvae preferentially settled in dense patches of gem clams. Considering the close taxonomic affinity and similarities in shape, living depth and feeding type, competi. tion for food or space might occur between newly settled hard clams and adult gem clams following settlement.

Unlike juvenile or adult hard clams, which reside deeply in sediment with siphons exposed at the sediment surface, newly settled hard clams are asiphonate, so suspension-feeding is restricted to surface sediment, or shallow pore water in porous sediment (Carriker 1961). Hence feeding exposes them to epibenthic predators and environmental stresses. Until siphons fully develop, hard clams spend their time alternating between byssal attachment and crawling. Rivara (1985) observed that juvenile hard clams up to $1 \mathrm{~mm}$ burrowed into sediment at the onset of illumination, but remained at the surface in darkness. Negative phototaxis may be a remnant of a larval adaptation. but this response may help control trade-offs between surface feeding and sub-surface avoidance of predators. We investigate here how biotic and environmental factors modulate this trade-off.

The present study investigated interactions between newly settled hard clams and adult gem clams. The effects of a dense gem clam population on emigration, growth and survival of newly settled hard clams were determined, and differential Gemma gemma effects on post-settlement processes of hard clams between substrates were demonstrated.

\section{MATERIALS AND METHODS}

Mercenaria mercenaria larvae were obtained from a hatchery company (Bluepoints Co., Inc.) and cultured until they metamorphosed (200 $\mu \mathrm{m}$ length at settlement) (Loosanoff 1959). Gemma gemma (2 to $5 \mathrm{~mm}$ in shell length) were collected from the intertidal zone of Flax Pond, a Spartina salt marsh on the north shore of Long Island, New York, USA. Both hard and gem clams were allowed to acclimate to experimental conditions for at least $3 \mathrm{~d}$. Both bivalve species were fed on Isochrysis galbana (clone T-iso; $4 \mu \mathrm{m}$ ) during acclimation and experimental periods.

Clean, medium-sized (250 to $500 \mu \mathrm{m}$ ) sand and muddy sand (10 mud:90 sand, w.w) were used as substrates. Sediment was prepared as described in Ahn et al. (1993).

Experimental conditions in the laboratory were similar to early summer conditions in. Great South Bay with respect to illumination, temperature and salinity. See Ahn et al. (1993) for added details. Unless otherwise stated, seawater was filtered through $0.2 \mu \mathrm{m}$ cartridge filters.

Upon completion of an experiment, sediment containing clams was collected by siphoning, preserved with buffered $5 \%$ formalin, and stained with rose bengal. Gem clams were sieved out on a $1 \mathrm{~mm}$ sieve and hard clams were extracted by mixing and decantation. Ahn et al. (1993) describes methods in more detail.

ANOVA and multiple comparisons among means (Sokal \& Rohlf 1981) were used to test statistical significance of experimental factors. Assumptions for ANOVA were tested and transformations were employed where appropriate.

Emigration Expt 1: effects of Gemma gemma, sediment type and food concentration. In preliminary experiments, recovery of hard clams varied with experimental treatments. Apparently, a number of hard clams emigrated from where they were initially transplanted. In this experiment, we determined the effects of a dense G. gemma population, sediment type and food concentration on emigration of newly settled Mercenaria mercenaria.

The experiment was conducted in a $38 \mathrm{l}$ glass aquarium filled with seawater to a depth of $15 \mathrm{~cm}$. Water was recirculated constantly at $2 \mathrm{I} \mathrm{min}^{-1}$ by airlifting (Kinne 1976) through 2 L-shaped PVC tubes at diagonally opposite corners; turnover time was $9.5 \mathrm{~min}$.

Treatments consisted of sand or muddy sand with 0 or $70 \mathrm{gem}$ clams $5.5 \mathrm{~cm}^{-2}$; each combination was run at 2 food concentrations ( 1 to $2 \times 10^{4}$ and 0.5 to $1 \times 10^{5}$ cells $\left.\mathrm{ml}^{-1}\right)$. Each treatment was kept in a separate petri dish ( $6 \mathrm{~cm}$ diameter, $1 \mathrm{~cm}$ depth) modified to estimate emigration rates. A plastic cylindrical well $(2.65 \mathrm{~cm}$ diameter and $2 \mathrm{~cm}$ height) was glued to the center of each petri dish. Each well was filled up to the rim with prepared sediment. The rest of the dish was covered with a $2 \mathrm{~mm}$ layer of sand. Three replicates of each treatment were then placed in the aquarium in a completely randomized design.

Gem clams were placed into the cylinders Approximately $24 \mathrm{~h}$ later, 200 hard clams $(259 \mu \mathrm{m}$ in mean shell length) were put into each cylinder. The experiment ran for $1 \mathrm{wk}$, then sediment was collected both from cylinders and surrounding areas in petri dishes, and retrieved hard clams were counted. Preliminary observations determined that hard clams which dropped from cylinders into petri dishes did not climb up. Emigration rate was expressed as percentage of clams collected from the surrounding area of the total retrieved

Emigration Expt 2: effect of Gemma gemma in the field. The effect of $G$. gemma patches on Mercenaria mercenaria emigration was tested in Flax Pond, 6 to 9 September 1989. We measured movement of postsettlement hard clams from sieved $(<1 \mathrm{~mm}$ ) Flax Pond 
sediment with 0 or $120 \mathrm{G}$. gemma $10 \mathrm{~cm}^{-2}$. The sediment was a muddy sand mixed with shell fragments.

Three replicates for each treatment were prepared in cubical freezer boxes $\left(10^{3} \mathrm{~cm}^{3}\right)$. A small cylindrical cage $\left(10 \mathrm{~cm}^{2}, 5 \mathrm{~cm}\right.$ high) of $1.6 \mathrm{~mm}$ mesh Nytex was pushed halfway into each freezer box; cages prevented Gemma gemma from emigrating but allowed Mercenaria mercenaria to move freely in and out of the cage. For the gem clam treatment, 120 G. gemma were placed within each appropriate cage and were allowed to acclimate in a flowing seawater system for $24 \mathrm{~h}$. Then 250 newly (a few days after settlement) metamorphosed hard clams (264 $\mu \mathrm{m}$ mean shell length) were pipetted inside each cage. Freezer boxes were then placed into a holding table in a completely randomized design $(2 \times 3$ array). The table was covered by a Nytex screen (1.6 mm mesh) to exclude small predators such as Crangon septemspinosa, and placed in a metal cage (1 $\mathrm{cm}$ mesh) to exclude larger predators such as mud crabs.

The table was kept $10 \mathrm{~cm}$ off bottom to reduce sedimentation. The cage was placed in a shallow subtidal channel. Water depth at low tide was about $5 \mathrm{~cm}$ above freezer boxes, and tidal range was about $1.6 \mathrm{~m}$. Freezer boxes were retrieved after $3 \mathrm{~d}$, and the top $1 \mathrm{~cm}$ of sediment was collected from Nytex cages and preserved. The effect of Gernma gemma on the emigration rate of newly metamorphosed Mercenaria mercenaria was measured

Growth Expt 1: effects of densities. Effects of Gemma gemma and Mercenaria mercenaria densities on growth and survival of early post-settlement $M$. mercenaria were tested. This experiment was run twice, one trial using a high food level, the other with low food. Since there was seasonal variation in size of adults ( 2.4 to $3.0 \mathrm{~mm}$ in mean shell length), the number of G. gemma for low (27 to 50 clams well ${ }^{-1}$ ) and high ( 110 to 200 clams well ${ }^{-1}$ ) density treatments was determined on the basis of total wet weight (low: $25 \mathrm{mg}$ $\mathrm{cm}^{-2}$; high: $100 \mathrm{mg} \mathrm{cm}^{-2}$ ). These densities were well within the natural range (Bradley \& Cooke 1959, Sanders et al. 1962, Sellmer 1967, Green \& Hobson 1970, Thomson 1982).

The trials were conducted in a glass aquarium as described earlier, except that aeration was from airstones from 4 sides. Eight multi-well plates $(12.7 \times 8.5 \times$ $1.7 \mathrm{~cm})$ were filled with clean sand. Each plate consisted of 6 wells $(3.6 \mathrm{~cm}$ diam., $1 \mathrm{~cm}$ depth).

Growth and survival of hard clams were assessed at zero, low and high Gemma gemma densities (see above). Gem clams were transplanted into wells and allowed to acclimate to experimental conditions. Three replicates for each treatment were placed in wells in a completely randomized design, and plates were then placed in the aquarium. Twenty-four hours later, newly metamorphosed hard clams were pipetted into wells at densities of 50, 200 and 1000 clams well $^{-1}$. Seawater was changed every other day throughout the 2 wk experimental period. The first trial ran all $G$. gemma $\times$ Mercenaria mercenaria combinations at a low food level ( 1 to $2 \times 10^{4} \mathrm{~T}$-iso cells $\mathrm{ml}^{-1}$ ) and the second trial used a high algal concentration 10.5 to $1 \times$ $10^{5} \mathrm{~T}$-iso cells $\mathrm{ml}^{-1}$ ).

Size of hard clams was determined with an optical pattern recognition system (Biosonics, Inc.). Mean initial shell lengths were identical among treatments. Final shell lengths were used as a measure of growth. At the end of each experiment minimum sample sizes for unbiased sample means were determined (Cochran 1963, p. 77). Minimum samples were taken from each replicate for measurement of shell length. Survival rate was expressed as percentage of clams alive at the end of an experiment to total clams retrieved.

Growth Expt 2: effects of density and sediment type. The purpose of this experiment was to evaluate separate and combined effects of Gemma gemma density and sediment type on Mercenaria mercenaria growth. Experimental design was similar to Expt 1. Two $G$. gemma densities were used, 0 and 120 clams well $^{-1}$. Each density was tested in sand and muddy sand.

Mechanism Expt 1: effect of sediment thickness. Based on the results of the growth experiments, we conducted several additional experiments to elucidate mechanisms. This experiment was conducted to determine the effects of sediment thickness on hard clam growth. Sediments of different thickness were used to simulate differences in sediment chemistry caused by physical activities of Gemma gemma. Irrigation activity of macrofauna can increase pore water exchange with overlying water, and remove inhibitory metabolites from the sediment (Aller 1982). In a thin sediment layer, pore water equilibrates easily with overlying water, thus it is analogous to a well-irrigated sediment ( $R$. Aller pers. comm.). Thicker sediment layers have gradients of metabolites in the pore water.

A thin sediment layer also constrains the burrowing depth of hard clams; clams in a thin layer are kept near the surface while animals in a thicker layer can burrow.

Mercenaria mercenaria growth was assessed in sediment layers of $3 \mathrm{~mm}, 1 \mathrm{~cm}$ and $3 \mathrm{~cm}$ depth. Cylindrical PVC containers were filled to appropriate depths with clean sand. Four replicates for each sediment thickness were then placed in a Plexiglas container in a completely randomized design $(3 \times 4$ array). Seawater was aerated and changed every other day over a $2 \mathrm{wk}$ period. Algal food was provided $\left(0.5\right.$ to $1 \times 10^{5} \mathrm{~T}$-iso cells $\mathrm{ml}^{-1}$ ). This experiment was conducted twice.

Mechanism Expt 2: retention efficiencies of algae and biodeposits. This experiment was run to test 
whether Gemma gemma biodeposits are used as food by newly settled hard clams. ${ }^{14} \mathrm{C}$-labeled algae were prepared by growing Isochrysis galbana in presence of ${ }^{14} \mathrm{C}$-bicarbonate $\left(1 \mu \mathrm{Ci} \mathrm{ml}{ }^{-1}\right.$ culture) for $5 \mathrm{~d}$ at $20{ }^{\circ} \mathrm{C}$ under constant illumination. Labeled cells were harvested and cleaned by centrifugation 3 to 4 times ( 4000 rpm, or $3000 \times \mathrm{g}$, for $15 \mathrm{~min}$ each time), and resuspended in unlabeled seawater.

A total of 150 Gemma gemma (3 $\mathrm{mm}$ ) were fed ${ }^{14} \mathrm{C}$-labeled algae (5 to $6 \times 10^{5}$ cells $\mathrm{ml}^{-1}$ ) for $40 \mathrm{~min}$, then were transferred to unlabeled algae at the same concentration. After $1 \mathrm{~h}$ gem clams were removed. ${ }^{14} \mathrm{C}$ biodeposits, produced by clams feeding on labeled algae, were concentrated on a $1.0 \mu \mathrm{m}$ Nuclepore membrane filter, and then resuspended in $50 \mathrm{ml}$ seawater. The biodeposit suspension was divided into 5 aliquots (10 ml each), 1 for measurement of ${ }^{14} \mathrm{C}$ loss and 4 for feeding to hard clams.

For measuring retention of biodeposits, 4 groups of 100 Mercenaria mercenaria $(350 \mu \mathrm{m}$ mean shell length) were placed in beakers of unlabeled algae. Aliquots of biodeposit suspensions were then added and hard clams were allowed to eat for $40 \mathrm{~min}$. Algal depletion during the feeding experiment was less than $5 \%$ of initial concentration. Then clams were transferred to beakers of unlabeled algae. Subsequent transfers were made every $2 \mathrm{~h}$ for $8 \mathrm{~h}$. After each transfer, algae and feces were collected separately on glass fiber filters. The experiment was conducted at $23^{\circ} \mathrm{C}$

Algal absorption by post-settlement Mercenaria mercenaria was measured using similar protocol. Eight groups of 80 hard clams (498 $\mu$ m mean shell length) were fed labeled algae. Labeling method and experimental procedure were as described above.

Filters and clams were placed in LSC vials and $10 \mathrm{ml}$ scintillant (Scintiverse II, Fisher) was added. Samples were eluted for $3 \mathrm{~d}$ before counting. ${ }^{14} \mathrm{C}$ activity was estimated by liquid scintillation (LKB-Wallac 1217), using external standards quench correction. Because ${ }^{14} \mathrm{C}$-DOC was not estimated, retention efficiency was calculated as a conservative measure of absorption efficiency. Retention efficiency was calculated as the ratio of ${ }^{14} \mathrm{C}$ retained in clams to the total ${ }^{14} \mathrm{C}$ defecated and retained in clams

Mechanism Expt 3: effect of biodeposits. This experiment was conducted to determine whether biodeposits affect hard clam growth. Growth of newly settled Mercenaria mercenaria was assessed for the following treatments: (1) no biodeposits; (2) 0.1 to 0.2 mg dry wt biodeposits $\mathrm{d}^{-1}$ (produced by 25 gem clams, $3 \mathrm{~mm}$ ); (3) 0.4 to $0.8 \mathrm{mg}$ dry wt biodeposits $\mathrm{d}^{-1}$ (produced by 100 gem clams). Each treatment was added to a $250 \mathrm{ml}$ beaker having $2 \mathrm{~mm}$ layer of sand and $200 \mathrm{ml}$ aerated seawater. Two hundred newly meta- morphosed hard clams (257 $\mu$ m mean shell length) were pipetted into each beaker.

Each day, biodeposits were collected on a $20 \mu \mathrm{m}$ sieve $(70 \%$ of particles were 20 to $30 \mu \mathrm{m})$ from gem clams and added to the beakers. Gem clams were fed 0.5 to $1 \times 10^{5}$ cells $\mathrm{ml}^{-1} \mathrm{~T}$-iso. Prior to daily addition of biodeposit, $75 \%$ of the seawater was changed using a siphon to avoid disturbing sediment. Hard clams were provided with 0.5 to $1 \times 10^{5}$ cells $\mathrm{ml}^{-1} \mathrm{~T}$-iso as a primary food source over the $2 \mathrm{wk}$ experimental period.

\section{RESULTS}

\section{Emigration}

In Emigration Expt 1, presence of gem clams increased hard clam emigration under both high and low food concentrations (Fig. 1). In their absence, $>95 \%$ of hard clams remained within the cylinders. More emigration occurred in muddy sand than in sand under high food concentration, and overall emigration rates were significantly higher under low than under high food concentration (Fig. 1). Interaction between Gemma gemma and Food was highly significant (Table 1). Other treatment interactions (G. gemma $\times$ Sediment, Sediment $\times$ Food, and G. gemma $\times$ Sediment $x$ Food) were not significant (Table 1). Survival was high $(>97 \%)$, and there was < $1 \%$ difference in survival between migrators and non-migrators. From 87.3 to $96.7 \%$ of the hard clams were retrieved from

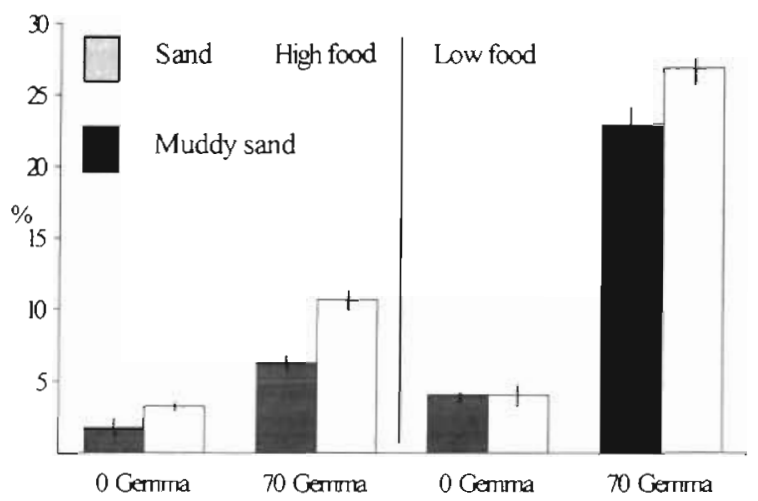

Fig. 1 Emigration Expt 1. Effects of Gemma gemma, sediment type and food concentration on emigration of newly settled Mercenaria mercenaria. Means ( $\pm 1 \mathrm{SE}$ ) of emigration rates for 3 replicate samples. Emigration is measured as percent of initial number of hard clams (200) that moved out of cylinders. Food concentration: high, 0.5 to $1 \times 10^{5}$ cells ml $^{-1}$;

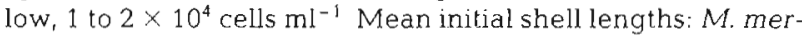
cenaria, $259 \mu \mathrm{m} ; \mathrm{G}$. gemma, $2.8 \mathrm{~mm}$. There was higher migration in the presence of gem clams at both food concentrations. Under high food, there was more $(p<0.01)$ migration in muddy sand than in sand. See Table 1 for ANOVA results 
Table 1. Emigration Expt 1. Three-way ANOVA table for the effects of Gemma gemma, sediment type and food concentration on emigration rate of newly settled Mercenaria mercenaria. $\cdots p<001 ;{ }^{\cdots} 0.001<p<0.01$; ns: not significant

\begin{tabular}{|lrcrrl|}
\hline Source & SS & df & \multicolumn{1}{c}{ MS } & $F_{\mathrm{S}}$ & \\
\hline G. gemma & 1090.53 & 1 & 1090.53 & 226.35 & $\cdots$ \\
Sediment & 43.63 & 1 & 43.63 & 9.06 & $\cdots$ \\
Food & 489.79 & 1 & 489.79 & 101.66 & $\cdots$ \\
G. gemma $\times$ Sediment & 21.36 & 1 & 21.36 & 4.43 & $\mathrm{~ns}$ \\
G. gemma $\times$ Food & 323.99 & 1 & 323.99 & 67.25 & $\cdots$ \\
Sediment $\times$ Food & 0.93 & 1 & 0.93 & 0.19 & $\mathrm{~ns}$ \\
G. gemma $\times$ Sediment $\times$ Food & 0.41 & 1 & 0.41 & 0.08 & $\mathrm{~ns}$ \\
Error & 77.09 & 16 & 4.82 & & \\
& & & & & \\
\end{tabular}

both cylinders and the rest of the petri dish. For reasons not understood, significantly fewer hard clams were retrieved from treatments containing gem clams (Table 2).

In Emigration Expt 2, the presence of Gemma gemma did not increase Mercenaria mercenaria emigration rate (Fig. 2). Emigration rates were higher in this field experiment than in the previous laboratory experiment.

\section{Growth}

Table 2. Emigration Expt 1. Effect of Gemma gemma, sediment type and food concentration on recovery of Mercenaria mercenaria. Recovery efficiency of hard clams: total percent recovered (cylinder and petri dish) of initial 200 added. Means $( \pm \mathrm{SD}), \mathrm{n}=3$. Initial shell lengths: $M$. mercenaria, $259 \mu \mathrm{m} ;$ G. gemma, $2.8 \mathrm{~mm}$. Retrieval rates were significantly lower in presence of $G$. gemma (3-way ANOVA: $F_{\mathrm{S}}=10.938$,

$$
\mathrm{p}<0.01)
$$

\begin{tabular}{|c|c|c|}
\hline \multirow[t]{2}{*}{ Sediment type } & \multicolumn{2}{|c|}{ G. gemma cylinder-1 } \\
\hline & 0 & 70 \\
\hline \multicolumn{3}{|c|}{ High food concentration ( 0.5 to $1 \times 10^{5}$ cells $\left.\mathrm{ml}^{-1}\right)$} \\
\hline Sand & $90.0(6.50)$ & $87.3(6.17)$ \\
\hline Muddy sand & $96.3(2.93)$ & $89.0(0.87)$ \\
\hline \multicolumn{3}{|c|}{ Low food concentration ( 1 to $2 \times 10^{4}$ cells $\mathrm{ml}^{-1}$ ) } \\
\hline Sand & $92.2(2.57)$ & $87.7(4.62)$ \\
\hline Muddy sand & $96.7(0.76)$ & $88.5(4.77)$ \\
\hline
\end{tabular}

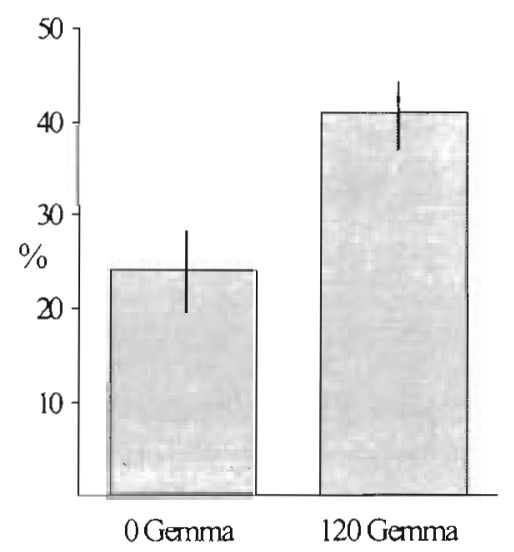

Fig. 2. Emigration Expt 2. Effect of Gemma gemma density on emigration of newly settled Mercenaria mercenaria in a $3 \mathrm{~d}$ field experiment. Means ( $\pm 1 \mathrm{SE}$ ) of migration rates for 3 replicate samples. Migration rate presented as percent of initial hard clams (250 per plot) that left their plot. G. gemma densities are per $10 \mathrm{~cm}^{2}$. Mean shell length of $M$. mercenaria was $264 \mu \mathrm{m}$, for G. gemma $2.9 \mathrm{~mm}$. $F_{S}=6.6319(\mathrm{p}<0.10)$
Growth Expt 1 demonstrated that the presence of gem clams enhanced hard clam growth at both low and high algal concentrations (Fig. 3a, b). Multiple comparisons among means (Welsch step-up procedure) showed that growth rate increased with increas-
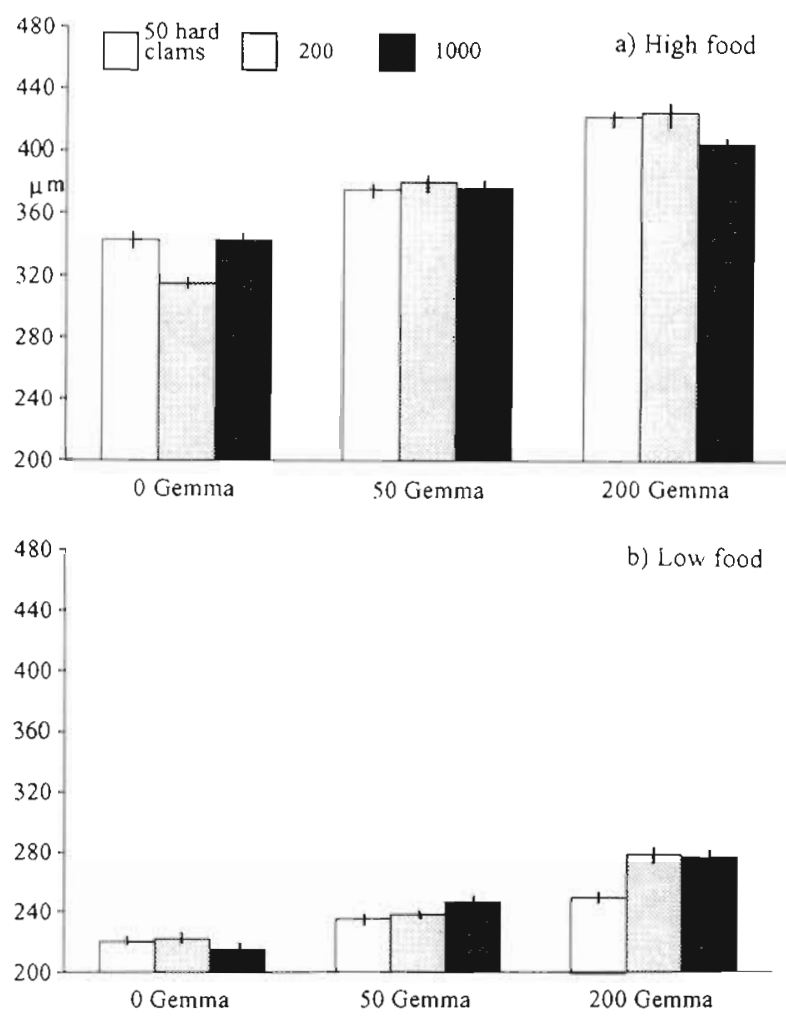

Fig. 3. Growth Expt 1. Effects of Gemma gemma and Mercenaria mercenaria densities on growth of newly settled $M$. mercenaria. Means ( $\pm 1 \mathrm{SE}$ ) of final shell lengths are shown. Samples were pooled from 3 replicates. $M$. mercenaria density ranged from 50 to 1000, G. gemma from 0 to 200. (a) High food treatment; mean initial shell length of $M$. mercenaria was $225 \mu \mathrm{m}$ ( $\pm 3.0 \mathrm{SE}$ ). (b) Low food, mean initial shell length of $M$. mercenaria was $200 \mu \mathrm{m}( \pm 2.1 \mathrm{SE})$. Mean shell length of $G$. gemma was $2.4 \mathrm{~mm}$. See Table 3 for ANOVA 
Table 3. Growth Expt 1 Two-way ANOVA tables for the effects of Gemma gemma density, Mercenaria mercenaria density, and interaction for high and low food concentrations. $\cdots p<0.001$; ns: not significant

\begin{tabular}{|c|c|c|c|c|c|}
\hline Source & SS & df & MS & $F_{\mathrm{S}}$ & \\
\hline \multicolumn{6}{|c|}{ High food concentration ( 0.5 to $1 \times 10^{5}$ cells $\left.\mathrm{ml}^{-1}\right)$} \\
\hline M. mercenaria & 5705 & 2 & 2853 & 1.43 & ns \\
\hline G. gemma & 939453 & 2 & 469727 & 236 & $\cdots$ \\
\hline M. mercenaria $\times$ G. gemma & 52234 & 4 & 13059 & 6.55 & $\cdots$ \\
\hline Error & 1595999 & 801 & 1993 & & \\
\hline \multicolumn{6}{|c|}{ Low food concentration ( 1 to $2 \times 10^{4}$ cells $\mathrm{ml}^{-1}$ ) } \\
\hline M. mercenaria & 26023 & 2 & 13011 & 13.5 & $\cdots$ \\
\hline G. gemma & 366651 & 2 & 183326 & 189.8 & $\cdots$ \\
\hline M. mercenaria $\times$ G. gemma & 1516 & 4 & 379 & 0.4 & ns \\
\hline Error & 790350 & 818 & 966 & & \\
\hline
\end{tabular}

Table 4. Growth Expt 1. Effects of intra- and inter-specific Gemma gemma and Mercenaria mercenaria densities and food concentration on survival of newly settled $M$. mercenaria. Survival is expressed as percentage of living clams of the total number of clams at the end of the experiment. Means (SD) for 3 replicate samples

\begin{tabular}{|c|c|c|c|}
\hline \multirow[t]{2}{*}{ M. mercenaria $10 \mathrm{~cm}^{-2}$} & \multicolumn{3}{|c|}{ G. gernma $10 \mathrm{~cm}^{-2}$} \\
\hline & 0 & 50 & 200 \\
\hline \multicolumn{4}{|c|}{ High food concentration $\left(0.5\right.$ to $1 \times 10^{5}$ cells ml $\left.{ }^{-1}\right)$} \\
\hline 50 & $98.7(2.19)$ & $98.8(1.06)$ & $98.7(1.10)$ \\
\hline 200 & $97.0(1.05)$ & $98.5(0.42)$ & $99.0(0.36)$ \\
\hline 1000 & $97.5(1.46)$ & $99.5(0.00)$ & $99.1(0.26)$ \\
\hline \multicolumn{4}{|c|}{ Low food concentration ( 1 to $2 \times 10^{4}$ cells $\mathrm{ml}^{-1}$ ) } \\
\hline 50 & $73.9(6.22)$ & $77.3(0.87)$ & $71.6(5.35)$ \\
\hline 200 & $74.0(10.2)$ & $87.1(6.31)$ & $88.0(2.49)$ \\
\hline 1000 & $65.0(10.2)$ & $73.5(10.8)$ & $83.5(1.38)$ \\
\hline
\end{tabular}

ing density of gem clams in both low and high food levels. There was no intra-specific density effect for Mercenaria mercenaria under high food. There was an intra-specific density effect (Table 3, 2-way ANOVA: $F_{\mathrm{S}}=13.466, \mathrm{p}<0.001$ ) at lower food, although multiple comparisons among means showed no significant intraspecific density effects within the density range tested. There was a significant Gemma gemma $\times$ Mer-cenaria mercenaria interaction in the high food trial, but not under low food (Table 3).

Survival rates in the high food trial were very high, ranging from 97.0 to $99.5 \%$ (Table 4 ). There was no effect of intraor inter-specific densities on Mercenaria mercenaria survival. In the lower food trial, survival rates were reduced, ranging from 65 to $88 \%$ (Table 4). There were significant $(p<0.05)$ intra- and inter-specific density effects on survival of newly settled hard clams, although the differences were relatively small. Multiple comparisons among means (Welsch step-up procedure) showed no significant negative intra- or inter-specific density effect on survival.

In Growth Expt 2, effect of gem clams on post-settlement Mercenaria mercenaria growth was strikingly different in sand and muddy sand. In sand, dense Gemma gemma populations consistently enhanced hard clam growth, as they did in Growth Expt 1. In muddy sand, the same G. gemma density reduced hard clam growth (Fig. 4). The effects of $G$. gemma, Sediment, and $G$. gemma $\times$ Sediment interaction all were significant (Table 5). Interestingly, the fastest growth rate occurred in muddy sand without G. gemma.

Survival rates were $>90 \%$ among treatments except in muddy sand containing gem clams (Table 6). Gemma gemma, Sediment and G. gemma $\times$ Sediment interaction significantly affected Mercenaria mercenaria survival (Table 7 ). Thus both survival and growth of hard clams were reduced in the presence of gem clams in muddy sand.

\section{Mechanisms of growth enhancement}

Fig. 4. Growth Expt 2. Effect of Gemma gemma density and sediment type on growth of newly settled Mercenaria mercenarla. Algal food was at 0.5 to $1 \times 10^{5} \mathrm{cel}_{\mathrm{s} \mathrm{ml}}^{-1}$ over a $2 \mathrm{wk}$ experimental period. Means ( $\pm 1 \mathrm{SE}$ ) of final shelj. length $(\mu \mathrm{m})$ for 3 replicate samples $(n=120 ; 40$ from each replicate). Initial mean shell length of hard clams was $226( \pm 2.86 \mathrm{SE}) \mu \mathrm{m}$, of $G$ gemma, $2.9 \mathrm{~mm}$. See Table 5 for ANOVA
In Mechanism Expt 1 hard clams grew faster in shallower sediments in both trials (Fig. 5). Trends were similar in both trials while pairwise comparisons differed slightly (Fig. 5). 
Table 5. Growth Expt 2. Two-way ANOVA table for the effects of Gemma gemma density and sediment type on Mercenaria mercenaria growth. $\cdots p<0.001 ; \cdots 0.001<p<0.01$

\begin{tabular}{|lrrrrr|}
\hline Source & \multicolumn{1}{c}{ SS } & df & MS & \multicolumn{1}{c|}{$F_{\mathrm{S}}$} & \\
\hline G. gemma & 24112 & 1 & 24112 & 8.64 & $\cdots$ \\
Sediment & 44352 & 1 & 44352 & 15.89 & $\cdots$ \\
$\begin{array}{l}\text { G. gemma } \times \text { Sediment } \\
\text { Error }\end{array}$ & 186832 & 1 & 186832 & 66.95 & $\cdots$ \\
& 1328393 & 476 & 2791 & & \\
\hline
\end{tabular}

Table 6. Growth Expt 2. Effect of Gemma gemma and sediment type on Mercenaria mercenaria survival. Survival rate expressed as percentage of clams remaining alive at the end of the experiment to the total number retrieved. Means (SD) for 3 replicate samples. Initial mean shell length of hard clams was $226 \mu \mathrm{m}$ in both sediment types. Mean shell length of $G$. gemma was $2.9 \mathrm{~mm}$. ' 'Survival rate of hard clams was significantly $(p<0.001)$ reduced in presence of gem clams in muddy sand; interaction term between G. gemma and sediment (2-way ANOVA; $\left.F_{S}=13.1968\right)$ is highly significant $(p<0.01)$

\begin{tabular}{|lcc|}
\hline Sediment type & \multicolumn{2}{c|}{ G. gemma $10 \mathrm{~cm}^{-2}$} \\
& 0 & 120 \\
\hline Sand & $97.2(1.14)$ & $92.0(4.38)$ \\
Muddy sand & $98.6(1.61)$ & $81.6(2.84)$ \\
\hline
\end{tabular}

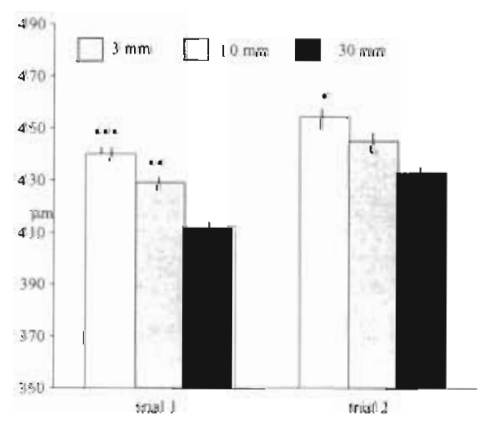

Fig. 5. Mechanism Expt 1. Effect of sediment thickness on growth of newly settled Mercenaria mercenaria. Means $( \pm 1$ SE) of final shell length $(\mu \mathrm{m})$ for 3 replicate samples ( 33 subsamples for each replicate in Trial 1, 40 in Trial 2). Mean initial shell length of $M$. mercenaria was $215 \mu \mathrm{m}$ in Trial 1,226 $\mu \mathrm{m}$ in Trial 2. $0.01<\mathrm{p}<0.05_{i}{ }^{*} 0.001<\mathrm{p}<0.01 ;{ }^{\cdots} \cdot \mathrm{p}<0.001$

Table 7 Growth Expt 2. Two-way ANOVA table for the effects of Gemma gemma density and sediment type on Mercenaria mercenaria survival. $\cdots p<0.001 ; \cdots 0.001<p<0.01 ; \cdot 0.01<p<0.05$

\begin{tabular}{|lrcrrl|}
\hline Source & SS & df & MS & \multicolumn{1}{cl}{$F_{\mathrm{S}}$} & \\
\hline G. gemma & 383.6 & 1 & 386.6 & 47.4 & $\cdots$ \\
Sediment & 60.6 & 1 & 60.6 & 7.8 &. \\
G. gemma $\times$ Sediment & 102.6 & 1 & 102.6 & 13.2 & $\cdots$ \\
Error & 62.2 & 8 & 7.8 & & \\
\hline
\end{tabular}

Mechanism Expt 2 showed that ${ }^{14} \mathrm{C}$ retention efficiency of radiolabeled biodeposits by newly settled Mercenaria mercenaria averaged only $4.5 \%$ ( $\pm 0.56 \mathrm{SE}$ ), much lower than the $76.7 \%( \pm 0.78)$ absorption of ${ }^{14} \mathrm{C}$-Isochrysis galbana

In Mechanism Expt 3, hard clams exposed to high input of Gemma gemma biodeposits grew more slowly than control clams (Fig. 6). Addition of a small amount of biodeposits had no effect on growth.

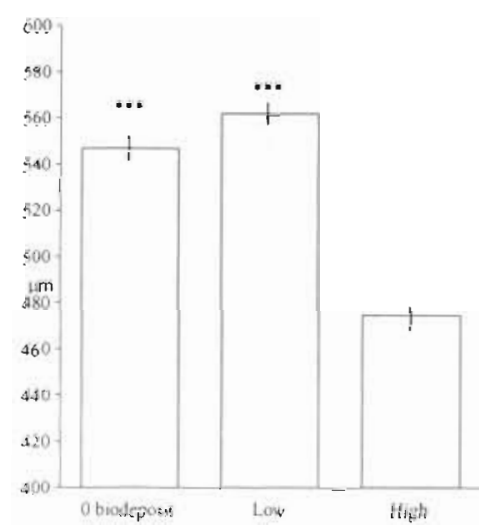

Fig. 6. Mechanism Expt 3. Effect of Gemma gemma biodeposit addition on Mercenaria mercenaria growth. Means ( \pm 1 SE) of final shell lengths $(\mu \mathrm{m})$ for 3 replicate samples ( $\mathrm{n}=120 ; 40$ from each replicate). Initial size of $M$. mercenaria was $257 \mu \mathrm{m}$. Low biodeposit was collected from ca $25 \mathrm{G}$. gemma ( $3 \mathrm{~mm}$ in shell length); high biodeposit was collected from ca 100 G. gemma. ' Significantly ( $p<0.001$ ) different from high treatment. There was no significant difference between control and low addition treatment

\section{DISCUSSION}

We were surprised to find that dense assemblages of Gemma gemma could enhance growth of Mercenaria mercenaria post-settlement. There are no theories or studies that would have led to predict these results. Most studies have shown negative effects of dense assemblages on growth (Williams 1979, Peterson \& Andre 1980, Peterson 1982, Peterson \& Black 1987, Gallagher et al. 1990), settlement (Sanders et al. 1962, Woodin 1976, Williams 1980, Peterson 1982) and emigration (Muus 1973, Luckenbach 1984), but Wilson (1981) made a critical point that relative and absolute sizes of interacting species may play 'a crucial role in determining the outcome of interspecific or inter-functional group interactions'. This is especially the case for interference, and less so for exploitative competition.

Emigration experiments demonstrated that hard clams in dense patches of gem clams 
quickly moved away. Microscopic observation showed that emigration from the cylinders occurred within a few days after transplantation. Once they emigrated from the crowded cylinders, they ceased crawling and anchored themselves to sand grains using byssal threads. Most emigrants were found near borders between cylinders and surrounding plots. Hard clams remaining in cylinders containing gem clams were scattered, and alternated between crawling, burrowing and byssal attachment. It is possible that hard clams accidentally fell from cylinders due to reworking by gem clams. The fact that the effect of gem clams on hard clam emigration was enhanced at the lower food concentration implies that emigration was not totally accidental.

Emigration rates were higher in the field experiment (Emigration Expt 2) than in the laboratory; emigration rates were as high as $41.3 \%$ over a $3 \mathrm{~d}$ period in the presence of Gemma gemma and $23.7 \%$ in its absence (Fig. 2). Cage baffling caused accumulation of a $2 \mathrm{~mm}$ layer of mud in containers left for $3 \mathrm{~d}$ in the field site (e.g. Nowell \& Jumars 1984). Deposition may have made the substrate less favorable for newly settled hard clams, and could have caused them to migrate out of the cages.

Newly settled hard clams may have moved away from Gemma gemma because the larger gem clams destabilized the sediment, making it locally unsuitable for small postlarvae (Rhoads \& Young 1970, Luckenbach 1984, Posey 1990). Interference of feeding by resuspension was probably more important in muddy sand than in sand, but the difference in emigration rates between sand and muddy sand was not as great as the difference between presence and absence of gem clams. An alternative mechanism is interference by direct contact. Significant emigration under lower algal concentration with gem clams indicates that emigration might also have been driven partly by exploitative competition for food.

The most surprising results of this study demonstrated that Gemma gemma could enhance post-settlement growth of hard clams, but their influence was altered greatly by sediment type (Fig. 4). In sand, increased G. gemma density consistently enhanced Mercenaria mercenaria growth (Fig. 3). During these experiments, brooding gem clams released as many as 2000 juveniles well $^{-1}$ (at the high adult density), especially under high food concentration. Juvenile gem clams were similar in size (300 to $400 \mu \mathrm{m})$ and behavior to post-settlement $M$. mercenaria. Nevertheless, hard clams grew better in sand when crowded with adult and juvenile G. gemma than in their absence. In muddy sands the reverse was true (Fig. 4); juvenile hard clams grew much better in the absence of $G$. gemma. Curiously, growth in muddy sands without $G$. gemma exceeded that in sands with G. gemma (Fig . 4). Unbioturbated muddy sand can be compacted and not easily penetrable, a condition which may be conducive to growth of suspension feeders (Rhoads \& Young 1970).

The effect of the Gemma gemma-sediment type interaction on Mercenaria mercenaria growth could be explained by a single mechanism; any factor that keeps small hard clams at the sediment surface results in greater growth. Enhanced growth in shallower sediment (Fig. 5) supports the suggestion that longer surface residence time increases $M$. mercenaria growth, perhaps due to increased feeding time. Post-settlement M. mercenaria do not have siphons, so it is likely that they feed only when at or very near the sediment surface (Carriker 1961). There is no evidence that they deposit-feed.

This mechanism provides a reasonable explanation for Mercenaria mercenaria growth in muddy sand. In the absence of bioturbating gem clams, muddy sand would be somewhat compacted and have a thin oxidized layer overlying a reduced layer, both of which would keep hard clams near the sediment surface. Bioturbation by gem clams makes muddy sand a much poorer substrate for post-settlement $M$. mercenaria; it increases the water content, making sediment less stable for small suspension feeders and increases the likelihood of being clogged with fine sediment (Rhoads \& Young 1970). Elmgren et al. (1986) demonstrated the converse for a deposit-feeding bivalve; in the presence of amphipods, spat survived less in a shallow sediment than in a thicker layer.

We suggest that the same mechanism, increased surface residence, can explain enhanced growth of newly settled hard clams in the presence of Gemma gemma in clean sand. Microscopic observations indicated that when newly settled hard clams crawl (e.g. when they emigrate from gem clam patches), they stay at or within a few grain layers from the sediment surface. Thus, hard clams may spend more time at the surface when they emigrate from $G$. gemma patches. We suggest further that they suspension-feed while they crawl, so they spend more time eating when they are migrating than when they stay put. This scenario is speculative and would be totally unconvincing except that it is consistent with enhanced Mercenaria mercenaria growth in a thin layer of sediment (Fig. 5). It is possible that growth was enhanced because there was more effective pore water exchange in the thin sediment layer, but the fact that very clean sand was used in this experiment lessens the likelihood that metabolite buildup in the pore water affected hard clam growth. It is more likely that clams in a thin layer of sediment were continuously exposed to overlying suspended algae, while those in deeper layers partitioned 
their time between surface feeding and deeper burrowing. Further investigation is needed to test this suggested interpretation, but it is consistent with all of our data.

There is an intriguing implication of this suggested interpretation regarding selective pressures on early life history of Mercenaria mercenaria, and perhaps many other burrowing, suspension-feeding bivalves. Undisturbed hard clams in sand grow more slowly than those constrained to the sediment surface. They appear not to grow at maximum rate unless they are kept at the surface, despite the obvious advantages to growing out of this vulnerable size class. Epibenthic predation is the probable selective pressure counteracting surface suspension-feeding (Muus 1973, Peterson 1979). Clams partition time between the necessary risk of surface suspension-feeding and the safe but energetically unprofitable deeper refuge. Interaction between opposing selective pressures is often invoked but is rarely taken into account in interspecific competitive interactions.

Growth enhancement in sand was not due to utilization of Gemma gemma feces and pseudofeces by Mercenaria mercenaria. Low retention efficiencies of $G$. gemma biodeposits by $M$. mercenaria indicate that biodeposits were ingested but were only slightly absorbed. Microscopic examination showed that $G$. gemma biodeposits produced from 5 to $6 \times 10^{5}$ cells $\mathrm{ml}^{-1}$ algal food consisted mostly of feces. Hence, that biodeposits had little nutritional value for newly settled hard clams is reasonable. The 'particle' size of biodeposits ( 20 to $30 \mu \mathrm{m}$ diameter compared to $4 \mu \mathrm{m}$ for Isochrysis galbana) may have reduced ingestion rates.

Growth reduction at high concentration of biodeposits indicates that biodeposition by a dense gem clam population did not contribute to enhanced hard clam growth. At high deposition rates, biodeposits might reduce hard clam growth by clogging gills or by stimulating metabolite buildup. Addition of low concentrations did not reduce growth of newly settled hard clams. Biodeposition could be beneficial to some deposit feeders (Commito \& Boncavage 1989), but not for newly settled, suspension-feeding hard clams

Survival rates of Mercenaria mercenaria were very high and were not affected by intra- or inter-specific densities at high food concentration (Table 4). Survival rates were reduced at lower food levels. Difference in survival rates may have resulted from using different batches of clams and food rather than from food concentration. Overall, dense Gemma gemma populations did not reduce survival of newly settled hard clams in sand even when food was restricted.

Dense Gemma gemma populations in muddy sand did reduce hard clam survival (Table 6). Microscopic examination showed that dead hard clams were close to their initial size, indicating either that death occurred early in the experiment, or that clams with lower growth rates did not survive. Burial by sediment reworking, together with exposure to pore water metabolites, may have contributed to mortality. However, even at the highest $G$. gemma density in muddy sand, hard clams survival was $>80 \%$. Dense patches of gem clams do not appear to severely affect survival of newly settled hard clams.

Gemma gemma density and sediment grade had complex effects on patterns of growth and emigration of early post-settlement Mercenaria mercenaria, which can be interpreted by postulating that any mechanism that increases surface residence time leads to more rapid growth of hard clams. This mechanism could explain why hard clams grew faster in a shallow layer of sand than in a deeper layer of the same clean sediment. We suggest that enhanced growth in sand in presence of $G$. gemma was an indirect effect of increasing emigration rate; clams may migrate mostly at the sediment surface. Results in muddy sand are also consistent with the proposed mechanism. The primary implication of this explanation is that early post-settlement, asiphonate hard clams do not grow as fast as they could at a given food concentration because the opposing selective pressures require hard clams to partition time between necessary surface feeding and deeper refuge from surface predation.

Acknowledgements. We thank Robert Aller, Robert Cerrato and Darcy Lonsdale for their advice in conducting this research. We give special thanks to Sally Woodin for her advice and criticism throughout this project. We acknowledge the Blue Point Company for providing clam larvae; Craig Strong and Stan Czyzyk were especially helpful in providing technical advice on culturing Ilard clams. This work was supported by the New York Sea Grant Institute.

\section{LITERATURE CITED}

Ahn, I.-Y., Malouf, R., Lopez, G. (1993). Enhanced larval settlement of the hard clam Mercenaria mercenaria by the gem clam Gemma gemma. Mar. Ecol. Prog. Ser. 99: 51-59

Aller, R. C. (1982). The effects of macrobenthos on chemical properties of marine sediment and overlying water. In: McCall, P. L., Tevesz, M. J. S. (eds.) Animal-sediment relations. Plenum, New York, p. 53-102

Botton, M. L. (1984). Effects of laughing gull and shorebird predation on the intertidal fauna at Cape May, New Jersey. Estuar coast. Shelf Sci. 18: 209-220

Bradley, W. H., Cooke, R. (1959). Living and ancient populations of the clam Gemma gemma in a Maine coastal tidal flat. Fish. Bull. U.S. 58: 304-334

Brenchley, G. A. (1981). Disturbance and community structure: an experimental study of bioturbation in marine softsediment environments. J. mar. Res. 39: 767-790

Carriker, M. R. (1961). Interrelation of functional morphology, behavior, and autecology in early stages of the bivalve, Mercenaria mercenaria. J. Elisha Mitch. Sci. Soc. 77: $168-241$ 
Cochran, W. G. (1963). Sampling techniques, 2nd edn. John Wiley and Sons, Inc., New York

Commito, J. A., Boncavage, E. M. (1989). Suspension feeders and coexisting infauna: an enhancement counter example. J. exp. mar. Biol. Ecol. 125: 33-42

Elmgren, E., Ankar, S., Marteleur, B., Ejdung, G. (1986) Adult interference with postlarvae in soft sediments: the Pontoporeia-Macoma example. Ecology 67: 827-836

Gallagher, E. D., Gardner, G. B., Jumars, P. A. (1990). Competition among the pioneers in a seasonal soft-bottom benthic succession: field experiments and analysis of the Gilpin-Ayala model. Oecologia 83: 427-442

Gallagher, E. D., Jumars, P. A., Trueblood, D. D. (1983). Facilitation of soft-bottom benthic succession by tube builders. Ecology 64: 1200-1216

Green, R. H., Hobson, K. D. (1970). Spatial and temporal structure in a temperate intertidal community with special emphasis on Gemma gemma (Pelecypoda: Mollusca). Ecology 51: 999-1011

Kinne, O. (ed.). (1976). Marine ecology, Vol. III, Cultivation, Part I. John Wiley \& Sons, New York

Levin, L. A. (1981). Dispersion, feeding behavior and competition in two spionid polychaetes. J. mar. Res. 39: $99-117$

Loosanoff, V. L. (1959). The size and shape of metamorphosing larvae of Venus (Mercenaria) mercenaria grown at different temperatures. Biol. Bull. 117: 308-318

Luckenbach, M. W. (1984). Settlement and early post-settlement survival in the recruitment of Mulinia lateralis (Bivalvia). Mar. Ecol. Prog. Ser. 17: 245-250

Maurer, D., Watling, L., Kinner, P., Leathem, N., Wethe, C. (1978). Benthic invertebrate assemblages of Delaware Bay. Mar. Biol. 45: 65-78

Muus, K. (1973). Settling, growth and mortality of young bivalves in the Øresund. Ophelia 12: 79-116

Nowell, A. R. M., Jumars, P. A. (1984). Flow environments of aquatic benthos. A. Rev. Ecol. Syst. 15: 303-328

Peterson, C. H. (1979). Predation, competitive exclusion, and diversity in the soft-sediment benthic communities of estuaries and lagoons. In: Livingson, R. L. (ed.) Ecological processes in coastal and marine ecosystems. Plenum, New York, p. 233-264

Peterson, C. H. (1982). The importance of predation and intraand inter-specific competition in the population biology of two infaunal suspension-feeding bivalves, Protothaca staminea and Chione undatella. Ecol. Monogr. 52: 437-475

Peterson, C. H., Andre, S. V. (1980). An experimental analysis of interspecific competition among marine filter feeders in a soft-sediment environment. Ecology 61: 129-139
Peterson, C. H., Black, R. (1987). Resource depletion by active suspension feeders on tidal flats: influence of local density and tidal elevation. Limnol. Oceanogr. 32: 143-166

Posey, M. H (1990). Function approaches to soft-substrate communities: how useful are they. Rev aquat. Sci. 2 $343-356$

Rhoads, D. C., Young, D. K. (1970). The influence of depositfeeding organisms on sediment stability and community trophic structure. J. mar. Res. 28: 150-178

Rivara, G. J. (1985). Effects of light and water flow on the burrowing response of Mercenaria mercenaria plantigrades. M.S. thesis, State Univ. New York, Stony Brook

Sanders, H. L., Goudsmit, E. M., Mills, E. L., Hampson, G. E (1962). A study of the intertidal fauna of Barnstable Harbor, Massachusetts. Limnol. Oceanogr. 7:63-79

Sellmer, G. P. (1967). Functional morphology and ecological life history of the gem clam, Gemma gemma (Eulamellibranchia: Veneridae). Malacologia 5: 137-223

Sokal, R. R., Rohlf, F. J. (1981). Biometry, 2nd edn. Freeman, San Francisco

Tamaki, A. (1985). Inhibition of larval recruitment of Armandia sp. (Polychaeta: Opheliidae) by established adults of Pseudopolydora paucibranchiata (Okuda) (Polychaete: Spionidae) on an intertidal sand flat. J. exp. mar. Biol. Ecol. 87: 67-82

Thomson, J. K. (1982). Population structure of Gemma gemma (Bivalvia: Veneridae) in south San Francisco Bay with a comparison to some northeastern United States estuarine populations. Veliger $24: 281-290$

Williams, J. G. (1979). Growth and survival in newly settled spat of the manila clam, Tapes japonica. Fish. Bull. U.S. 77: $891-900$

Williams, J. G. (1980). The influence of adults on the settlement of spat of the clam. Tapes japonica. J. mar. Res. 38: $729-741$

Wilson, W. H. Jr (1980). A laboratory investigation of the effect of terebellid polychaete on the survivorship of nereid polychaete larvae. J. exp. mar. Biol. Ecol. 46: 73-80

Wilson, W. H. Jr (1981). Sediment-mediated interactions in a densely populated infaunal assemblage: the effects of the polychaete Abarenicola pacifica. J. mar. Res. 39: 735-748

Woodin, S. A. (1976). Assemblages: patterns of abundance. J. mar. Res. 34: 25-41

Woodin, S. A. (1981). Disturbance and community structure in a shallow water sand flat. Ecology 62: 1052-1066

Woodin, S. A. (1985). Effects of defecation by arenicolid polychaete adults on spionid polychaete juveniles in field experiment: selective settlement or differential mortality. J. exp. mar. Biol Ecol. 87: 119-132

Manuscript first received: July 31, 1992

Revised version accepted: April 5, 1993 